\title{
Optimasi Kasus Pengaturan Kombinasi Pemuatan n Paket Barang ke m Kotak Angkut
}

\author{
Optimization for Loading Arrangement of $\mathrm{n}$ Boxes to $\mathrm{m}$ \\ Transportation Box
}

\author{
Ria Asih Aryani Soemitro ${ }^{1, a)}$ \& Hitapriya Suprayitno ${ }^{2, b)}$ \\ ${ }^{1)}$ Departemen Teknik Sipil, Institut Teknologi Sepuluh November, Surabaya \\ ${ }^{2)}$ Departemen Teknik Sipil, Institut Teknologi Sepuluh November, Surabaya
}

Koresponden : ${ }^{\text {a) }}$ soemitroraa@gmail.com \& b) suprayitno.hita@gmail.com

\begin{abstract}
ABSTRAK
MAI mengandung banyak Kasus Optimasi. Dengan demikian pemanfaatan Riset Operasional bagi MAI perlu untuk dieksplorasi. Optimasi Kasus Pengangkutan Sampah Tipe SCS penting untuk dilakukan. Penyusunan Metoda Optimasi dilakukan dalam 4 tahap dan Penyusunan Tahap 1 sudah diselesaikan. Metoda Optimasi Tahap 2 perlu untuk dibangun, yang berupa : optimasi kombinasi pengaturan $\mathrm{n}$ barang ke $\mathrm{m}$ kotak angkut. Metoda Optimasi ini telah berhasil dibangun. Prinsip optimasi adalah meminimalkan ruang sisa tiap kotak angkut. Algoritma Optimasi mengikuti 3 langkah utama : susun urutan ukuran barang dari besar ke kecil, keluarkan barang angkut yang tidak layak angkut dan susun kombinasi pemuatan barang yang menghasilkan ruang sisa minimal, secara bertahap dimulai dari ukuran besar ke kecil. Metoda Optimasi telah berhasil di-uji-coba.
\end{abstract}

Kata Kunci : manajemen aset infrastruktur, manajemen operasi, infrastruktur sampah padat, kombinasi pemuatan barang untuk meminimalkan jumlah kotak angkut.

\section{PENDAHULUAN}

Manajemen Aset Infrastruktur (MAI) mengandung pengertian "memaksimalkan manfaat sambil meminimalkan biaya". Dengan demikian Optimasi merupakan bagian yang tidak terpisahkan dari MAI. Optimasi merupakan isi dari Riset Operasional (RO), yang sudah dikembangkan sangat jauh sejak kisaran tahun 1940an (Hillier \& Lieberman 1990). Oleh karena itu, pemakaian berbagai teknik RO bagi MAI perlu untuk dikaji. Selain itu pembangunan Metoda Optimasi untuk Kasus-Kasus MAI perlu untuk dibangun. Simulasi juga bisa dipakai dalam perencanaan, perancangan dan optimasi infrastruktur (Susanti, Soemitro, Suprayitno, 2017).

Pengangkutan sampah padat perkotaan dari TPS ke TPA termasuk kedalam Aspek Manajemen Operasi Infrastruktur Penanganan Sampah Padat. Secara umum, terdapat dua golongan sistem pengangkutan sampah padat : Hauled Container System (HCS) dan Stationary Container System (SCS). Kota Surabaya baru menerapkan Sistem Pengangkutan Tipe SCS. Metoda Optimasi Kasus HCS sudah pernah dibangun di Jurusan Teknik Sipil (Suprayitno, 2003), sedangkan Metoda Optimasi Kasus SCS belum pernah disusun.

Oleh karena itu Metoda Optimasi Kasus SCS perlu untuk dibangun. Kasus ini, dilihat dari sudut pandang Teknik Riset Operasional bukan suatu kasus sederhana (Suprayitno \& Soemitro, 2017). Oleh karena itu penyusunan Metoda Optimasi Kasus SCS diperkirakan perlu 
untuk dilakukan dalam beberapa tahap. Metoda Optimasi tahap pertama telah diselesaikan, berupa Optimasi Jumlah Kendaraan untuk menyinggahi semua Titik Singgah dengan Batasan Waktu Kerja Kendaraan (Suprayitno \& Soemitro, 2016). Penyusunan Metoda Optimasi selanjutnya ditujukan untuk menyusun Metoda Optimasi Jumlah Kotak Pengangkutan pada Kasus Pengaturan Kombinasi Pemuatan n Barang ke m Truk Angkut. Metoda Optimasi ini tidak bisa ditemukan pada referensi acuan bagi penelitian ini (Brandes \& Erlebach, 1998; Dimyati \& Dimyati, 1994; Goldberg, 2000; Hillier \& Lieberman, 1990; Indryani, Astana \& Suprayitno, 2004; Jaiswal, 1997; Khan, 1984; Pisinger, 1995; Srivastava \& Nema, 2006; Suprayitno, 1999; Suprayitno, 2001; Suprayitno, 2003; Suprayitno, 2014; Suprayitno 2015; Suprayitno \& Indryani, 1997; Suprayitno \& Indryani, 1997a; Suprayitno \& Soemitro, 2017; Taha, 1992; Wikipedia, 2015).

Oleh karena itu Metoda Optimasi Tahap Kedua perlu untuk dibangun. Tulisan ini ditujukan untuk menyampaikan hasil penyelesaian penyusunan Metoda Optimasi Tahap Kedua.

\section{STUDI PUSTAKA}

Kasus optimasi yang ditangani dalam penelitian ini adalah Kasus Pengaturan Kombinasi Pemuatan n Paket Barang kedalam m Angkut, dengan meminimalkan Jumlah Kotak Angkut.

Permasalahan ini, dilihat dari sudut pandang Riset Operasional, termasuk kedalam golongan Permasalahan Linier, yang bukan Masalah Jaringan. Metoda Optimasi yang sudah terbangun didalam golongan ini adalah : Programasi Linier, Programasi Linier Khusus (Permasalahan Transportasi, Permasalahan Transhipment, Permasalahan Penugasan), Integer Programming - dengan variasi pengembangannya, dan Knapsack Problem (Brandes \& Erlebach, 1998; Dimyati \& Dimyati, 1994; Goldberg, 2000; Hillier \& Lieberman, 1990; Indryani, Astana \& Suprayitno, 2004; Jaiswal, 1997; Khan, 1984; Suprayitno, 1999; Suprayitno, 2001; Suprayitno, 2003; Suprayitno 2014; Suprayitno 2015; Srivastava \& Nema, 2006; Suprayitno \& Indryani, 1997; Suprayitno \& Indryani, 1997a; Suprayitno, Mochtar \& Wicaksono 2014; Taha, 1992; Wikipedia, 2015).

Kasus Optimasi yang terlihat banyak miripnya dengan kasus ini adalah kasus Knapsack Problem. Knapsack Problem menangani permasalahan Optimasi Memaksimalkan Manfaat bagi Kombinasi Pemuatan n Barang ke sebuah Ransel. Diketahui sebuah Ransel dengan Kapasitas Muat Tertentu dan n Barang, yang masing-masing mempunyai Nilai Muat dan Nilai Manfaat Tertentu. Nilai Muat bisa diukur dalam satuan berat atau volume, atau yang lain. Sedangkan Nilai Manfaat bisa diukur dalam bentuk satuan uang, nilai kepentingan, atau yang lain (Khan, 1984; Pisinger, 1995; Wikipedia, 2015).

Metoda Optimasi dan Kasus Penelitian ini tidak ditemukan di referensi-referensi tersebut diatas. Oleh karena itu penyusunan Metoda Optimasi masih diperlukan.

\section{PENYUSUNAN METODA OPTIMASI AWAL}

\footnotetext{
Tahapan Umum Penyusunan Metoda Optimasi Kasus Pengangkutan Sampah Padat Tipe SCS.

Kasus Optimasi Pengangkutan Sampah Padat Tipe SCS, dilihat dari sudut pandang Teknik Riset Operasional, bukan suatu kasus sederhana. Oleh karena itu, secara umum, penyusunan Metoda Optimasi Kasus SCS diperkirakan sebaiknya dilakukan dalam 4 tahap. Tahap pertama adalah masalah optimasi persinggahan kendaraan. Tahap kedua adalah masalah optimasi kombinasi pemuatan $\mathrm{n}$ barang ke $\mathrm{m}$ jumlah kotak angkut. Tahap ketiga adalah masalah gabungan persinggahan dan kombinasi pemuatan. Tahap ke-empat adalah gabungan masalah ketiga dengan kendala urutan persinggahan karena adanya kendala jaringan jalan.
} 
Upaya penyusunan Metoda Optimasi Awal ini, untuk memudahkan proses penyusunan, dibatasi untuk Kasus Fiktif yang sangat disederhanakan. Dalam upaya awal ini, optimasi dilakukan untuk Tahap Kedua.

\section{Kasus Fiktif}

Kasus Fiktif dirumuskan sebagai berikut. Suatu Permasalahan Pengaturan Kombinasi Pemuatan $\mathrm{n}$ barang ke $\mathrm{m}$ Kotak Angkut. Meminimalkan Jumlah Kotak Angkut. Bentuk Barang Yang diangkut diabaikan. Yang diperhitungkan hanya Volume Barang Angkut dan Volume Kotak Angkut. Kasus seperti ini bisa terjadi pada kasus pengangkutan barang curah : seperti sampah padat, sampah cair, beras, gandum, dll.

\section{Model Grafis}

Permasalahan ini bisa dimodelkan dalam bentuk Model Grafis. Bentuk Model Grafis disampaikan pada Gambar 1 sebagai berikut.

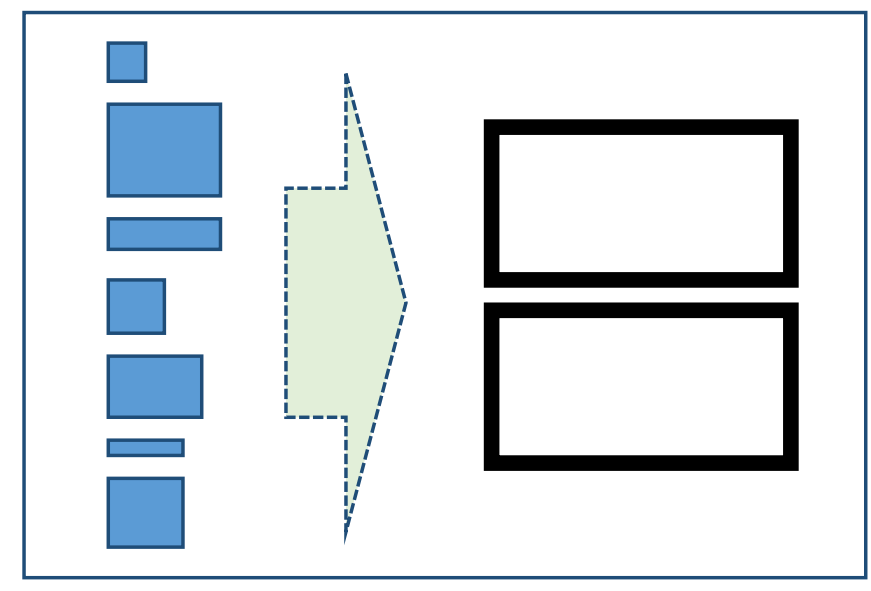

Gambar 1. Model Grafis Kasus Penelitian

\section{Model Matematis Optimasi}

Optimasi Kasus ini berupa meminimalkan jumlah Kotak Angkut untuk menampung seluruh Barang Angkut. Masalah dibatasi dengan hanya memperhitungkan Volume Barang Angkut dan Volume Kotak Angkut.

Dalam bentuk Matematis, Kasus Optimasi ini bisa dirumuskan sebagai berikut.

Min. $Z=m$

$$
\mathrm{T}_{\mathrm{m}}=\mathrm{T}_{1}, \mathrm{~T}_{2}, \ldots . . \mathrm{T}_{\mathrm{m}}
$$

Kendala :

$$
\begin{aligned}
& \mathrm{V}_{\mathrm{m}}=\sum \mathrm{B}_{\mathrm{m}, \mathrm{j}} \\
& \mathrm{B}_{\mathrm{m}, \mathrm{j}} \in\left|\mathrm{B}_{\mathrm{i}}\right| \\
& \mathrm{V}_{\mathrm{m}} \leq \mathrm{C}
\end{aligned}
$$

\section{Notasi}

$\mathrm{m}$ : jumlah kotak angkut yang terpakai

$\mathrm{T}_{\mathrm{m}}$ : kotak angkut ke $\mathrm{m}$

$\mathrm{V}_{\mathrm{m}}$ : volume barang total yang termuat di kotak angkut ke $\mathrm{m}$

$\mathrm{B}_{\mathrm{i}}$ : volume barang ke $\mathrm{i}$

$B_{m, j}$ : volume barang ke $j$, pada kotak angkut ke $m$ 


\section{C : kapasitas kotak angkut}

Teknik Optimasi yang digunakan didasarkan pada Ketentuan sebagai berikut. Meminimalkan Jumlah Kotak Angkut bisa tercapai dengan Meminimalkan Sisa Ruang untuk tiap Truk Angkut, setelah diisi dengan Kombinasi Optimal Barang Angkut.

\section{Algoritma Optimasi Pemecahan Masalah}

Algoritma disusun berdasarkan Tujuan dan Teknik Optimasi yang sudah diuraikan diatas. Oleh karena itu Rancangan Algoritma menjadi sebagai berikut.

- Keluarkan Barang Angkut yang tidak bisa dimuat.

- Susun Kombinasi Barang Angkut yang menghasilkan Volume Sisa Minimal, dengan metoda Enumerasi.

- Kombinasi dimulai dari Kotak dengan Volume terbesar, karena kotak ini memiliki jumlah kombinasi paling kecil. Kemungkinan kombinasi yang dimiliki paling kecil.

Algoritma :

- Susun urutan barang dimulai dari ukuran terbesar ke ukuran terkecil.

- Periksa keberadaan barang yang tidak bisa dimuat. Singkirkan.

- Susun kombinasi barang yang menghasilkan sisa volume terkecil, dimulai dari barang dengan ukuran terbesar. Penyusunan kombinasi dimulai dari Kombinasi 2 Barang Angkut, dilanjutkan dengan Kombinasi 3 Barang Angkut dan seterusnya, secara iteratif.

- Langkah ketiga diulangi sampai dengan seluruh barang selesai dimuat.

\section{UJI COBA METODA OPTIMASI}

Uji Coba Metoda Optimasi dilakukan dengan menggunakan Kasus Fiktif yang sangat disederhanakan. Perhitungan terdiri dari 4 macam langkah : Langkah Pengurutan Barang Angkut, Langkah Pemisahan Barang Angkut Tak Layak Terlayani, Langkah Penyusunan Kombinasi dan Langkah Rangkuman Hasil Perhitungan.

\section{Kasus Uji Coba}

Kasus Uji Coba ditentukan sebagai berikut. Suatu Kasus Kombinasi Pemuatan Barang Angkut terdiri dari 20 Barang Angkut dengan Ukuran yang bervariasi dari 2 - 22, dengan sejumlah Kotak Angkut dengan Ukuran 20. Susun kombinasi pemuatan Barang Angkut ke Kotak Angkut agar Jumlah Truk Angkut yang dibutuhkan minimal. Daftar Barang Angkut disampaikan pada Tabel 1 berikut ini.

Tabel 1. Data Barang Angkut

\begin{tabular}{|c|c|c|}
\hline No & Nama & Ukuran \\
\hline 1 & A & 2 \\
\hline 2 & B & 5 \\
\hline 3 & C & 7 \\
\hline 4 & D & 19 \\
\hline 5 & E & 10 \\
\hline 6 & F & 11 \\
\hline 7 & G & 3 \\
\hline 8 & H & 22 \\
\hline 9 & I & 4 \\
\hline 10 & J & 6 \\
\hline 11 & K & 17 \\
\hline 12 & L & 4 \\
\hline 13 & M & 13 \\
\hline 14 & N & 8 \\
\hline 15 & O & 9 \\
\hline
\end{tabular}




\section{Langkah 1 : Pengurutan Barang}

Langkah Pertama adalah pengurutan Barang Angkut kedalam Urutan dari Besar ke Kecil. Hasil pengurutan disampaikan pada Tabel 2 sebagai berikut.

Tabel 2. Daftar Urutan Barang Angkut

\begin{tabular}{|c|c|c|}
\hline No & Nama & Ukuran \\
\hline 1 & H & 22 \\
\hline 2 & D & 19 \\
\hline 3 & K & 17 \\
\hline 4 & M & 13 \\
\hline 5 & F & 11 \\
\hline 6 & E & 10 \\
\hline 7 & O & 9 \\
\hline 8 & N & 8 \\
\hline 9 & C & 7 \\
\hline 10 & J & 6 \\
\hline 11 & B & 5 \\
\hline 12 & I & 4 \\
\hline 13 & L & 4 \\
\hline 14 & G & 3 \\
\hline 15 & A & 2 \\
\hline
\end{tabular}

\section{Langkah 2 : Pemeriksaan Barang Tidak Bisa Dimuat}

Langkah ke 2 berupa Pemeriksaan Barang Tidak Bisa Dimuat. Barang Angkut yang mempunyai Ukuran lebih besar dari Kapasitas Angkut (20), tidak akan akan bisa dimuat kedalam Kotak Angkut. Barang H mempunyai ukuran $22>20$. Barang ini tidak dapat daingkut. Hasil pemeriksaan disampaikan pada Tabel 3 sebagai berikut.

Tabel 3. Pemeriksaan Barang Tidak Bisa Dimuat

\begin{tabular}{|c|c|c|}
\hline No & Nama & Uk uran \\
\hline 1 & $\mathrm{H}$ & 22 \\
\hline 2 & $\mathrm{D}$ & 19 \\
\hline 3 & $\mathrm{~K}$ & 17 \\
\hline 4 & $\mathrm{M}$ & 13 \\
\hline 5 & $\mathrm{~F}$ & 11 \\
\hline 6 & $\mathrm{E}$ & 10 \\
\hline 7 & $\mathrm{O}$ & 9 \\
\hline 8 & N & 8 \\
\hline 9 & $\mathrm{C}$ & 7 \\
\hline 10 & $\mathrm{~J}$ & 6 \\
\hline 11 & $\mathrm{~B}$ & 5 \\
\hline 12 & $\mathrm{I}$ & 4 \\
\hline 13 & $\mathrm{~L}$ & 4 \\
\hline 14 & $\mathrm{G}$ & 3 \\
\hline 15 & A & 2 \\
\hline
\end{tabular}

Setelah Barang Angkut H dikeluarkan, tersisa sejumlah 14 Barang Angkut. Tabel Data Barang Angkut Sisa, yang tersisa 14, disampaikan sebagai berikut. 
Tabel 4. Tabel Data Barang Angkut Sisa

\begin{tabular}{|c|c|c|}
\hline No & Nama & Ukuran \\
\hline 1 & D & 19 \\
\hline 2 & K & 17 \\
\hline 3 & M & 13 \\
\hline 4 & F & 11 \\
\hline 5 & E & 10 \\
\hline 6 & O & 9 \\
\hline 7 & N & 8 \\
\hline 8 & C & 7 \\
\hline 9 & J & 6 \\
\hline 10 & B & 5 \\
\hline 11 & I & 4 \\
\hline 12 & L & 4 \\
\hline 13 & G & 3 \\
\hline 14 & A & 2 \\
\hline
\end{tabular}

\section{Langkah 3 : Penyusunan Kombinasi 1}

Langkah ketiga berupa Peyusunan Kombinasi Barang Angkut, dimulai dari Kombinasi 2 Barang Angkut, selanjutnya diteruskan ke Kombinasi 3 Barang Angkut bila diperlukan. Penyusunan kombinasi dimulai dari Barang Angkut ukuran besar ke kecil.

Hasil penyusunan kombinasi menunjukkan bahwa dengan Barang Angkut D tidak ada kombinasi 2 barang angkut yang layak. Semua Ukuran Kombinasi melebihi Ukuran Kotak Angkut. Dengan demikian Barang Angkut D harus berdiri sendiri dengan Volume Isi Kotak Angkut T1 = 19 .

Tabel 4. Penyusunan Kombinasi 1

\begin{tabular}{|c|c|c|}
\hline No & Nama & Ukuran \\
\hline 1 & $\mathrm{D}$ & 19 \\
\hline 2 & $\mathrm{~K}$ & 17 \\
\hline 3 & $\mathrm{M}$ & 13 \\
\hline 4 & $\mathrm{~F}$ & 11 \\
\hline 5 & $\mathrm{E}$ & 10 \\
\hline 6 & $\mathrm{O}$ & 9 \\
\hline 7 & $\mathrm{~N}$ & 8 \\
\hline 8 & $\mathrm{C}$ & 7 \\
\hline 9 & $\mathrm{~J}$ & 6 \\
\hline 10 & $\mathrm{~B}$ & 5 \\
\hline 11 & $\mathrm{I}$ & 4 \\
\hline 12 & $\mathrm{~L}$ & 4 \\
\hline 13 & $\mathrm{G}$ & 3 \\
\hline 14 & $\mathrm{~A}$ & 2 \\
\hline
\end{tabular}

\begin{tabular}{|c|c|c|c|}
\hline \multicolumn{4}{|c|}{ PENYUSUNAN KOMBINASI 1} \\
\hline No & Kombi'i & Ukuran & Eval \\
\hline 1 & $\mathrm{D}+\mathrm{K}$ & 36 & $\mathrm{x}$ \\
\hline 2 & $\overline{D+M}$ & 32 & $\mathrm{X}$ \\
\hline 3 & $\mathrm{D}+\mathrm{F}$ & 30 & $\mathrm{x}$ \\
\hline 4 & $\mathrm{D}+\mathrm{E}$ & 29 & $\mathrm{x}$ \\
\hline 5 & $\mathrm{D}+\mathrm{O}$ & 28 & $\mathrm{X}$ \\
\hline 6 & $\mathrm{D}+\mathrm{N}$ & 27 & $\mathrm{x}$ \\
\hline 7 & $\mathrm{D}+\mathrm{C}$ & 26 & $\mathrm{x}$ \\
\hline 8 & $\mathrm{D}+\mathrm{J}$ & 25 & $\mathrm{x}$ \\
\hline 9 & $\mathrm{D}+\mathrm{B}$ & 24 & $\mathrm{x}$ \\
\hline 10 & $\overline{D+I}$ & 23 & $\mathrm{x}$ \\
\hline 11 & $\mathrm{D}+\mathrm{L}$ & 23 & $\mathrm{x}$ \\
\hline 12 & $\mathrm{D}+\mathrm{G}$ & 22 & $\mathrm{x}$ \\
\hline 12 & $\mathrm{D}+\mathrm{A}$ & 21 & $\mathrm{x}$ \\
\hline
\end{tabular}

Barang D sudah diselesaikan untuk dimuat, jadi harus dikeluarkan dari Daftar Barang Angkut yang harus dioptimasi. Data Barang Angkut Sisa yang baru disampaikan pada Tabel 5 sebagai berikut. 
Tabel 5. Tabel Data Barang Angkut Sisa Kombinasi 1

\begin{tabular}{|c|c|c|}
\hline No & Nama & Ukuran \\
\hline 1 & K & 17 \\
\hline 2 & M & 13 \\
\hline 3 & F & 11 \\
\hline 4 & E & 10 \\
\hline 5 & O & 9 \\
\hline 6 & N & 8 \\
\hline 7 & C & 7 \\
\hline 8 & J & 6 \\
\hline 9 & B & 5 \\
\hline 10 & I & 4 \\
\hline 11 & L & 4 \\
\hline 12 & G & 3 \\
\hline 13 & A & 2 \\
\hline
\end{tabular}

\section{Langkah 4 : Penyusunan Kombinasi 2}

Langkah selanjutnya adalah melakukan Penyusunan Kombinasi 2. Penyusunan dilakukan unutk Barang Angkut dengan Ukuran Terbesar. Investigasi susunan Kombinasi terbaik dilakukan dengan enumerasi semua kemungkinan kombinasi, kemudian setelahnya baru dipilih 1 Kombinasi terbaik. Hasil enumerasi mengindikasikan bahwa Kombinasi $\mathrm{K}+\mathrm{G}$ merupakan Kombinasi Terbaik dengan Ukuran Kombinasi $=17+3=20$. Hal ini berarti Sisa $=0$. Perhitungan Penyusunan Kombinasi disampaikan pada Tabel 6 sebagai berikut.

Tabel 6. Perhitungan Penyusunan Kombinasi 2

\begin{tabular}{|c|c|c|}
\hline No & Nama & Ukuran \\
\hline 1 & K & 17 \\
\hline 2 & M & 13 \\
\hline 3 & F & 11 \\
\hline 4 & E & 10 \\
\hline 5 & O & 9 \\
\hline 6 & N & 8 \\
\hline 7 & C & 7 \\
\hline 8 & J & 6 \\
\hline 9 & B & 5 \\
\hline 10 & I & 4 \\
\hline 11 & L & 4 \\
\hline 12 & G & 3 \\
\hline 13 & A & 2 \\
\hline
\end{tabular}

\begin{tabular}{|c|c|c|c|}
\hline \multicolumn{4}{|c|}{ PENUSUNAN KOMB INASI 2 } \\
\hline No & Komb'i & Nilai & Eval \\
\hline 1 & K+M & 30 & X \\
\hline 2 & $\mathrm{~K}+\mathrm{F}$ & 28 & $\mathrm{X}$ \\
\hline 3 & $\mathrm{~K}+\mathrm{E}$ & 27 & $\mathrm{X}$ \\
\hline 4 & $\mathrm{~K}+\mathrm{O}$ & 26 & $\mathrm{X}$ \\
\hline 5 & $\mathrm{~K}+\mathrm{N}$ & 25 & $\mathrm{X}$ \\
\hline 6 & $\mathrm{~K}+\mathrm{C}$ & 24 & $\mathrm{X}$ \\
\hline 7 & $\mathrm{~K}+\mathrm{J}$ & 23 & $\mathrm{X}$ \\
\hline 8 & $\mathrm{~K}+\mathrm{B}$ & 22 & $\mathrm{X}$ \\
\hline 9 & $\mathrm{~K}+\mathrm{I}$ & 21 & $\mathrm{X}$ \\
\hline 10 & $\mathrm{~K}+\mathrm{L}$ & 21 & $\mathrm{X}$ \\
\hline 11 & $\mathrm{~K}+\mathrm{G}$ & 20 & ok \\
\hline 12 & $\mathrm{~K}+\mathrm{A}$ & 19 & $?$ \\
\hline \multicolumn{4}{|c}{} \\
\hline
\end{tabular}

Seperti halnya langkah-langkah sebelumnya, langkah ini diikuti dengan penyusunan Tabel Data Barang Angkut Sisa, yang disampaikan pada Tabel 7 sebagai berikut.

Tabel 7. Tabel Barang Angkut Sisa Kombinasi 2

\begin{tabular}{|c|c|c|}
\hline No & Nama & Ukuran \\
\hline 1 & M & 13 \\
\hline 2 & F & 11 \\
\hline 3 & E & 10 \\
\hline 4 & O & 9 \\
\hline 5 & N & 8 \\
\hline 6 & C & 7 \\
\hline 7 & J & 6 \\
\hline 8 & B & 5 \\
\hline 9 & I & 4 \\
\hline 10 & L & 4 \\
\hline 11 & A & 2 \\
\hline
\end{tabular}




\section{Langkah 5 : Penyusunan Kombinasi 3}

Terlihat bahwa Barang Angkut Sisa masih cukup banyak. Tindakan selanjutnya adalah melakukan tindakan Iterasi Penyusunan Kombinasi. Hasil Penyusunan Kombinasi 3 menghasilkan Kombinasi $\mathrm{M}+\mathrm{C}$ dengan hasil Ukuran $=20$. Perhitungan disampaikan pada Tabel 8 sebagi berikut.

Tabel 8. Perhitungan Penyusunan Kombinasi 3

\begin{tabular}{|c|c|c|}
\hline No & Nama & Ukuran \\
\hline 1 & M & 13 \\
\hline 2 & F & 11 \\
\hline 3 & E & 10 \\
\hline 4 & O & 9 \\
\hline 5 & N & 8 \\
\hline 6 & C & 7 \\
\hline 7 & J & 6 \\
\hline 8 & B & 5 \\
\hline 9 & I & 4 \\
\hline 10 & L & 4 \\
\hline 11 & A & 2 \\
\hline
\end{tabular}

\begin{tabular}{|c|c|c|c|}
\hline \multicolumn{4}{|c|}{ PENYUSUNAN KOMB INASI 3 } \\
\hline No & Kombi'i & Nilai & Eval \\
\hline 1 & M+F & 24 & X \\
\hline 2 & M+E & 23 & X \\
\hline 3 & M+O & 22 & X \\
\hline 4 & M+N & 21 & X \\
\hline 5 & M+C & 20 & ok \\
\hline 6 & M+J & 19 & $?$ \\
\hline 7 & M+B & 18 & $?$ \\
\hline 8 & M+I & 17 & $?$ \\
\hline 9 & M+L & 17 & $?$ \\
\hline 10 & M+A & 15 & $?$ \\
\hline
\end{tabular}

Seperti diatas, langkah diatas diikuti dengan penyusunan Daftar Barang Angkutan Sisa. Hasil penyusunan disampikan pada Tabel 9 sebagai berikut.

Tabel 9. Daftar Barang Angkut Sisa Kombinasi 3

\begin{tabular}{|c|c|c|}
\hline No & Nama & Ukuran \\
\hline 1 & F & 11 \\
\hline 2 & E & 10 \\
\hline 3 & O & 9 \\
\hline 4 & N & 8 \\
\hline 5 & J & 6 \\
\hline 6 & B & 5 \\
\hline 7 & I & 4 \\
\hline 8 & L & 4 \\
\hline 9 & A & 2 \\
\hline
\end{tabular}

\section{Langkah 6 : Penyusunan Kombinasi 4}

Langkah ke 6, masih sangat sama dengan kedua langkah sebelumnya. Kombinasi Optimal yang dihasilkan adalah Kombinasi F+O dengan Nilai 20. Perhitungan penyusunan Kombinasi Optimal disampaikan pada Tabel 10 sebagai berikut.

Tabel 10. Perhitungan Penyusunan Kombinasi 4

\begin{tabular}{|c|c|c|}
\hline No & Nama & Ukuran \\
\hline 1 & F & 11 \\
\hline 2 & E & 10 \\
\hline 3 & O & 9 \\
\hline 4 & N & 8 \\
\hline 5 & J & 6 \\
\hline 6 & B & 5 \\
\hline 7 & I & 4 \\
\hline 8 & L & 4 \\
\hline 9 & A & 2 \\
\hline
\end{tabular}

\begin{tabular}{|c|c|c|c|}
\hline \multicolumn{4}{|c|}{ PENYUSUNAN KOMB INASI 4 } \\
\hline No & Kombi & Nilai & Eval \\
\hline 1 & F+E & 21 & $\mathrm{x}$ \\
\hline 2 & F+O & 20 & $\mathrm{x}$ \\
\hline 3 & $\mathrm{~F}+\mathrm{N}$ & 19 & $?$ \\
\hline 4 & $\mathrm{~F}+\mathrm{J}$ & 17 & $?$ \\
\hline 5 & $\mathrm{~F}+\mathrm{B}$ & 16 & $?$ \\
\hline 6 & $\mathrm{~F}+\mathrm{I}$ & 15 & $?$ \\
\hline 7 & $\mathrm{~F}+\mathrm{L}$ & 15 & $?$ \\
\hline 8 & $\mathrm{~F}+\mathrm{A}$ & 13 & $?$ \\
\hline
\end{tabular}


Setelah Langkah Kombinasi 4, Barang Angkut tersisa 7 buah. Daftar Barang Angkut Sisa disampaikan pada Tabel 11 sebagai berikut.

Tabel 11. Daftar Barang Angkut Sisa Kombinasi 4

\begin{tabular}{|c|c|c|}
\hline No & Nama & Ukuran \\
\hline 1 & E & 10 \\
\hline 2 & N & 8 \\
\hline 3 & J & 6 \\
\hline 4 & B & 5 \\
\hline 5 & I & 4 \\
\hline 6 & L & 4 \\
\hline 7 & A & 2 \\
\hline
\end{tabular}

Langkah 7 : Penyusunan Kombinasi 5

Penyusunan Kombinasi 5 secara prinsip sama dengan Penyusunan Kombinasi sebelumnya. Hanya pada langkah ini terjadi sesuatu yang baru. Penyusunan Kombinasi 2 Barang Angkut belum menghasilkan Kombinasi Optimal. Sehingga Penyusunan Kombinasi dilanjutkan dengan Kombinasi 3 Barang Angkut. Kombinasi Optimal adalah : E+N+A dengan Nilai 20. Perhitungan disampaikan pada Tabel 12 berikut ini.

Tabel 12. Perhitungan Penyusunan Kombinasi 5

\begin{tabular}{|c|c|c|c|c|c|c|c|c|c|c|}
\hline No & Nama & Ukuran & \multicolumn{8}{|c|}{ PENYUSUNAN KOMB INASI 5} \\
\hline 1 & $\mathrm{E}$ & 10 & No & Kombi 2 & Nilai & Eval & No & Kombi 3 & Nilai & Eval \\
\hline 2 & $\mathrm{~N}$ & 8 & 1 & $\mathrm{E}+\mathrm{N}$ & 18 & 8 & & & & \\
\hline 3 & $\mathbf{J}$ & 6 & 2 & $\mathrm{E}+\mathrm{J}$ & 16 & $?$ & 1 & $\mathrm{E}+\mathrm{N}+\mathrm{J}$ & 24 & $\mathrm{x}$ \\
\hline 4 & $\mathrm{~B}$ & 5 & 3 & $\mathrm{E}+\mathrm{B}$ & 15 & $?$ & 2 & $\mathrm{E}+\mathrm{N}+\mathrm{B}$ & 23 & $\mathrm{x}$ \\
\hline 5 & $\mathrm{I}$ & 4 & 4 & $\mathrm{E}+\mathrm{I}$ & 14 & $?$ & 3 & $\mathrm{E}+\mathrm{N}+\mathrm{I}$ & 22 & $\mathrm{x}$ \\
\hline 6 & $\mathrm{~L}$ & 4 & 5 & $\mathrm{E}+\mathrm{L}$ & 14 & $?$ & 4 & $\mathrm{E}+\mathrm{N}+\mathrm{L}$ & 22 & $\mathrm{x}$ \\
\hline 7 & A & 2 & 6 & $\mathrm{E}+\mathrm{A}$ & 12 & $?$ & 5 & $\mathrm{E}+\mathrm{N}+\mathrm{A}$ & 20 & ok \\
\hline
\end{tabular}

Sisa Barang Angkut dari Penyusunan Kombinasi 5 ada 4 Barang Angkut. Daftar Barang Angkut Sisa disampaikan pada Tabel 13 sebagai berikut.

Tabel 13. Daftar Barang Angkut Sisa Kombinasi 5

\begin{tabular}{|c|c|c|}
\hline No & Nama & Ukuran \\
\hline 1 & J & 6 \\
\hline 2 & B & 5 \\
\hline 3 & I & 4 \\
\hline 4 & L & 4 \\
\hline
\end{tabular}

\section{Langkah 8 : Penyusunan Kombinasi 6}

Seperti Langkah Penyusunan Kombinasi 5, langkah ini agak berbeda sedikit. Karena pada langkah sebelumnya, Kombinasi Optimal terjadi pada Kombinasi 3 Barang Angkut, maka proses Optimasi Kombinasi dimulai dari Kombinasi 3 Barang Angkut. Kombinasi Optimal terjadi pada Kombinasi 4 Barang Angkut : J+B+I+L dengan Nilai 19.

Tabel 14. Perhitungan Kombinasi 6

\begin{tabular}{|c|c|c|}
\hline No & Nama & Ukuran \\
\hline 1 & $\mathrm{~J}$ & 6 \\
\hline 2 & $\mathrm{~B}$ & 5 \\
\hline 3 & $\mathrm{I}$ & 4 \\
\hline 4 & $\mathrm{~L}$ & 4 \\
\hline
\end{tabular}$\quad$\begin{tabular}{|c|c|c|c|c|c|c|c|c|}
\hline \multicolumn{7}{|c|}{ PENYUSUNAN KOMBINASI 6 } \\
\hline No & Kombi 3 & Nilai & Eval & No & Kombi 4 & Nilai & Eval \\
\hline & & & & & & & & \\
\hline 1 & J+B+I & 15 & $?$ & & & & \\
\hline 2 & J $+\mathrm{B}+\mathrm{L}$ & 15 & $?$ & 1 & J $+\mathrm{B}+\mathrm{I}+\mathrm{L}$ & 19 & $\mathrm{ok}$ \\
\hline
\end{tabular}


Barang Angkut Sisa telah tiada. Berarti seluruh Proses Penyusunan Kombinasi telah diselesaikan.

\section{Rangkuman Hasil Perhitungan}

Perhitungan telah diselesaikan. Pokok-pokok Hasil Perhitungan secara ringkas disampaikan sebagai berikut : 1 barang tidak bisa dimuat dan 6 kotak angkut dengan 6 kombinasi barang angkut. Keseluruhan 20 Barang Angkut telah ditangani.

- Tidak bisa dimuat : H Nilai : 22

- Kombinasi l : D Nilai : 19

- Kombinasi $2 \quad: K+G \quad$ Nilai : 20

- Kombinasi 3 : M+C Nilai : 20

- Kombinasi 4 : F+O Nilai: 20

- Kombinasi 5 : E+N+A Nilai: 20

- Kombinasi 6 : J+B+I+L Nilai: 19

\section{KESIMPULAN}

Tujuan riset telah berhasil diselesaikan dengan baik. Pokok-pokok kesimpulan bisa disampaikan sebagai berikut.

- Optimasi tentang meminimalkan Jumlah Kotak Angkut untuk mengangkut sejumlah Paket Barang.

- Minimalisasi dilakukan dengan prinsip meminimalkan ruang sisa Kotak Angkut.

- Perhitungan Optimasi dilakukan secara bertahap.

Untuk memudahkan penyebutan, metoda optimasi ini sebaiknya diberi nama julukan tertentu. Penulis memberi nama julukan metoda optimasi ini dengan nama Metoda "Transportation Boxes Loading Problem".

Penelitian ini menghasilkan pertanyaan lanjutan, diantaranya penggabungan metoda optimasi ini dengan metoda optimasi minimalisasi Jumlah Truk Angkut untuk melayani beberapa titik pengambilan barang. Metoda optimasi ini telah disusun sebelumnya.

\section{DAFTAR PUSTAKA}

Dimyati, T.T. \& Dimyati A. (1994). Operation Research - Model-Model Pengambilan Keputusan. Sinar Baru Algesindo. Bandung.

Hillier, F.S. \& Lieberman, G.J. (1990). Introduction to Operation Research. Fifth Edition, Holden-Day Inc.. San Francisco.

Indryani, R., Astana, I.N.Y. \& Suprayitno, H (2004). "Model Transportasi untuk Pengembangan Pelayanan Air Bersih di Kabupaten Badung Bali". Jurnal TORSI; Edisi Maret 2004, Tahun ke 24 No 1. Jurusan Teknik Sipil. Institut Teknologi Sepuluh Nopember (ITS). Surabaya.

Jaiswal, N.K. (1997). Military Operations Research : Quantitative Decision Making. Kluwer Academic. Boston.

Khan, Lutfar Rahman (1984). "Rural Road Planning in Developing Countries : A Network Modeling Approach". Disertation. Asian Institute of Technology. Bangkok.

Munir, Rinaldi (2003). Matematika Diskrit. Edisi Kedua. Penerbit Informatika. Bandung.

Pissinger, David (1995). "Algorithms for Knapsack Problems". PhD Thesis. Department of Computer Science. University of Copenhagen. Copenhagen. 
Suprayitno, Hitapriya (1999). "Penyusunan Algoritma Bagi Pemecahan Permasalahan Optimasi Linier Umum Bersolusi Bilangan Bulat". Jurnal TORSI, Edisi Mei 1999, Tahun ke 19 No. 1. Jurusan Teknik Sipil, Institut Teknologi Sepuluh Nopember (ITS). Surabaya.

Suprayitno, Hitapriya (2001). "Model Preliminer Penjadwalan Sistem Manufaktur Arus Garis (Kasus Sistem Manufaktur Arus Garis Tunggal)". Jurnal TORSI, Edisi Nopember 2001, Tahun ke 21 No. 3. Jurusan Teknik Sipil, Institut Teknologi Sepuluh Nopember (ITS).

Suprayitno, Hitapriya (2003). "Optimasi Permasalahan Armada dan Trayek Angkutan : Kasus Sederhana Pengangkutan Sampah dari TPS ke TPA”. Jurnal TORSI, Edisi Juli 2003, Tahun ke 23 No 2. Jurusan Teknik Sipil, Institut Teknologi Sepuluh Nopember (ITS). Surabaya.

Suprayitno, Hitapriya (2014). "Correctness Proof of Min - Plus Algebra for All Network Shortest - Path Simultanious Calculation". Journal of Technology and Social Sciences (JTSS), Vol. 1, No.1, pp - 61 69, 2017. Surabaya.

Suprayitno, Hitapriya (2015). "Development Special Matrix Techique for Road Network Analysis". The 18 th FSTPT International Symposium, Agustus 28, 2015. Universitas Negeri Lampung. Bandar Lampung.

Suprayitno, Hitapriya \& Indryani, Retno (1997). "Masalah Transportasi Logistik Kasus dengan Beberapa Titik Asal dan Beberapa Titik Tujuan". Jurnal TORSI, Edisi Nopember 1996, Tahun ke 16, No. 2. Jurusan Teknik Sipil, Institut Teknologi Sepuluh Nopember (ITS). Surabaya.

Suprayitno, Hitapriya \& Indryani, Retno (1997a). "Metoda Perhitungan Proporsi : Metoda Pemecahan Masalah Transportasi Logistik". Jurnal TORSI, Edisi Mei 1997, Tahun ke 17, No. 1. Jurusan Teknik Sipil, Institut Teknologi Sepuluh Nopember (ITS). Surabaya.

Suprayitno, Hitapriya, Mochtar, I.B \& Wicaksono, A.I (2014). "A Special Matrix Power Operation Development for Simultaneous Calculation of All Network's Shortest Part". Jurnal of Theoritical \& Appled Information Technology, Vol.62, No.1, 2014. Surabaya.

Suprayitno, H \& Soemitro, RAAS (2017). "Upaya Awal Optimasi Jumlah Kendaraan Angkut Pada Kasus Umum Pengangkutan Obyek dari n Titik Asal ke 1 Titik Pengamatan". Jurnal Manajemen Aset Infrastruktur \& Fasilitas, Vol.1, No.1, Desember 2017. Jurusan Teknik Sipil, Institut Teknologi Sepuluh Nopember (ITS). Surabaya.

Susanti, A., Soemitro, R.A.A \& Suprayitno, H (2017). "Metoda Simulasi Bagi Perhitungan Kebutuhan Jumlah Tempat Duduk Pada Fasilitas Reservasi Tiket". Jurnal Manajemen Aset Infrastruktur \& Fasilitas, Vol.1, No.1, Desember 2017. Jurusan Teknik Sipil, Institut Teknologi Sepuluh Nopember (ITS). Surabaya.

Taha, Hamdy A. (1992). Operation Research - An Introduction. Fifth Edition. Maxwell Macmillan International. New York.

Wikipedia (2015). Knapsack Problems. https://en.wikipedia.org/wiki/Knapsack Problems [23/07/2015 21:42:26]. 
(e)ISSN 2615-1847 $\quad$ (p)ISSN 2615-1839

Jurnal Manajemen Aset Infrastruktur \& Fasilitas - Vol. 2, No. 1, Maret 2018 